\title{
Analysis of Implementation and Perception of Online Formative Assessment on Students' Speaking Skill at Sukasada
}

\author{
Gusti Ayu Agung Tania Gautami ${ }^{1}$ \\ Ganesha University of Education \\ agungtania20@gmail.com \\ Made Hery Santosa ${ }^{2}$ \\ Ganesha University of Education \\ mhsantosa@undiksha.ac.id
}

\begin{abstract}
This study investigated the perspective and the implementation of formative assessments by the teacher to the students in the SMPN 1 Sukasada. There were 1 English teacher and 11 students investigated as the informants. The data gained through closed-ended questionnaires and the teacher was interviewed by using Whatsapp chat. The result of this study shows that the teacher cannot assess the students' speaking skill during this pandemic. In the point of view of students, they thought that speaking is important but, they do not have any gadgets to support their improvement in speaking skill. Based on this result the teacher has important role in developing the students' language skills in order to achieve the objectives of the learning. The students also should be able to manage themselves during online learning. It is very challenging for both of participants in achieving the successes of the learning objectives.
\end{abstract}

Keywords: Formative Assessments, Online learning, Students' Speaking skill

\section{INTRODUCTION}

During the pandemic of COVID-19, many activities moved their way by using online platform. This way is chosen in order to decrease the number of the COVID-19 victims. Here the strategies of the government to make sure that the victims will not increase in this world. In Indonesia the government restricting the activities of all people and they should follow the rules. People who want to work or do their activities should be checked by the doctor and they should do rapid test to make sure they are not infected by Corona Virus. Rapid test is a vaccine that we use to indicate the virus infection. This vaccine is possible to quick result to get the result of the test. (Franzén, 2020).

Before the pandemic, the schools in the world do their activity as usual. They come to school and study in the classroom. They study through face-toface meeting and it is quite interesting for us. In Indonesia also have a similar way in doing the learning process before the pandemic. The teachers and the students do the learning process in the classroom and they mostly spend their time in the school. It is also easier because the students and the teacher can do the interaction directly. By that way also make the students and the teacher has closer relationship, because they meet almost every single day. The teacher also 
can easily assess all the students intensively, because the teacher may see the progress of the students directly.

While, after the pandemic happen in this world all the schools change their way in doing their activity. All schools in the world especially in Indonesia prefers to use online virtual meeting to teach their students during this pandemic. It is supported by Lestiyanawati \& Widyantoro (2020) who state that The Indonesian Minister of Education publishes an instruction for conducting online learning due to Covid-19 pandemic. Teachers are supposed to do an online learning in which the student studies from their homes. This new learning design brings a rapid change in education. As what Redmond (2020) states that the changing of teaching form which moved from face-to-face meeting into online meeting may change the learning design, besides that the role of the teacher and the students also will change the responsibility both of the participants. The teachers also should be able to design their learning process as interesting as they can. The other thing that is they also should be able to change their way and sometimes they also change their instrument in teaching. As we can see now the teacher should be prepare all the stuffs that can support the online learning process. It might be very challenging by the teacher, because not all the teacher especially in Indonesia can apply the technology in teaching. As an English teacher, they should be able to teach the four skills in language, such as Listening, Reading, Speaking, and Writing. It is not an easy thing to make sure the students will understand the material through online virtual learning.

Learning from home is not that easy, according to Searls (2014), there are several rules in designing the online meeting. Here the teacher should be able to apply the entire rules in order to make the learning process still like the previous style. The first rule is, the teacher should be able to make a new plan for online learning. The plan for traditional way in learning is quite different to the online learning plan. Here the teacher should provide extra tools in order to make the learning process going smoothly. The second rule is by giving exercise to the students, in this case the teacher should be able to design and to give some exercises to the students to make the teacher easier assessing the students. The third rules is doing assessment, here by using the exercise above, the teacher may know the progress of the students and the teacher can give value or score for the students. In addition, it is added that teachers are suggested for not giving the students exercises which are too difficult.

As the explanation above, the teacher should be able to assess their students even though they only meet via online learning. There is a kind of assessment which is called as Formative Assessment. According to Heritage (2010) formative assessment is an assessment which is used to assess the fundamental process and it is use to assess the practice in the learning process. Before the pandemic, the way of the teacher in assessing their students is easier. They can assess the students directly every meeting and they might know the progress of the students. But, after the pandemic the teacher should change their way in doing the assessments. Here because of the online learning, the teachers modify their way in assessment. The instrument that the teachers mostly use in assessing their students through online learning is by giving exercise to the students.

According to Lorenzo et al (2020) teacher professionalism depend on their confidence and their insufficient language skill. The professional teacher should be able to design the learning process as good as they can and it should 
be relevant with the students' need. The professional teacher should be able to prepare the activities before the class not only from the theory but also the teachers' argument of the problem. Bozkuş \& Bayrak (2019) states that EFL is learning English in non-English countries. For example, we learn English in Indonesia, while ESL is English as the second language for the learners. In the learning process, teacher should be able to assess their students' ability.

Generally, assessment takes place as the heart of the students' experience sine it has the biggest influence on how students approach their learning (Rust et al., 2005). Jimaa (2011) states that assessment is aimed at determining the progress level and the suitability of students' learning outcomes. It is stated that there are two types of assessments based on the way to assess the students, that are summative and formative assessments. In summative assessments the teacher mostly give the values for the students and it is mostly used to earn the certification (Irfan Tosuncuoglu, 2018). Formative assessments are used to make the students develop their learning deeply. It will use feedback and cultural responsiveness to make the students increase their interest in learning (Clark, 2011). In formative assessments, there is an assessment called as performance assessment.

Performance assessment is an assessment which expects the students to use their knowledge and their skill, the teacher will assess them from the process when they solving the problem (Bland \& Gareis, 2018). In this case, the teacher should be able to assess the EFL's students speaking skill. They could assess the speaking skill by using video practices or giving them a script and tell them to read and pay attention to the pronunciations of every word. Speaking is very important for the learners in using any languages, without this skill they cannot develop the information into written information. Speaking skill is one of the skills that the students should develop. They can train that skill by using song, story or many more. According to Qureshi (2017) which stated in the result of their research, in order to make the students massive in speaking skill they can give more opportunities to the students to learn about the language form. It will help the students in managing their pronunciation of words in English.

Mostly we see teachers assess the students' speaking skill by only using traditional assessment. However using traditional assessments is not enough to make the students know their competency in learning (Sewagegn, 2019). The teacher should be able to assess their students by using authentic assessments which is called as performance assessment. According to Arhin (2015), as the result, the performance assessment can help the teacher increasing the learners' interest in the learning process. By using performance assessments also, the students can increase their positive attitudes in the learning process to make them have positive experiences during the learning process.

Besides that, a researcher also has their result in using performance assessments in the learning process. Based on the result of this research, performance assessment helps the students to develop their inferential speaking skill. It means that a performance assessment gives an effect to the language skills (Salam \& Khalek, 2009). In another research also has a result about the speaking skill. In the result of Samira's research, the speaking skill difficulties are based on the students' linguistics difficulties, mother tongue use, and inhibition. The students also feel hard in speaking because they do not have enough vocabulary. The other researcher also stated that the students mostly afraid to speak because they afraid that the words they said are wrong (Hosni, 2015). 
After doing this research the teachers are expected to develop their techniques in assessing the EFL students' ability in speaking skill by using the performance assessments, which are suitable to gain the progress of the students in that skill

As we know all the language skills are important for the students. All of the cases that happened during this pandemic are given positive and negative impact in educational field. Here the roles of the teachers are very important in developing the students' language skills. It makes the writer wants to know what makes the other skills especially the speaking skill cannot be taught by the teacher by using online learning. The writer wants to know the challenges that the teacher found in teaching speaking skill through online learning. Besides that, the writer also wants to know how the teachers assess and the challenges in assessing the students' speaking skill through online learning.

According to the explanation above, the way that the teacher assesses the students' language skill should be proper with the current condition. During this pandemic, we may know that we will do all the activities from home. Here the teacher should be able to design the way in assessing the students' skill as possible as they can. It will help the parents know the progress of their children. Besides, the teachers also will easier in giving score to the students objectively. For the students, they will also know how far their ability in using English especially in speaking skill.

In this study the there are two research problems that gained from the phenomena above. The first research problem is what are the perceptions of the teacher during assessing their students' skill through online learning? The second research problem is how is the implementation of formative assessment through online learning in assessing the students' speaking skill in SMPN 1 Sukasada? Based on those research problems, there are two aims that this study provides. The first aim is to know the perceptions of the teacher during assessing their students' skill through online learning, and the second aim is to know how the implementation of formative assessment through online learning in assessing the students' speaking skill in SMPN 1 Sukasada.

\section{METHOD}

\section{Research Design}

In this research, the writer uses a mixed method to gain the data. Mixed method is a method which combining the way in gaining data by using qualitative and quantitative method (Doyle \& Brady, 2009). Here the writer wants to make the reader get the trustable data and valid data. We can see the sequence of gaining data by using mixed method in figure 1 bellow.

Figure1. The sequence of gaining data of mixed method (Creswell, 2012)

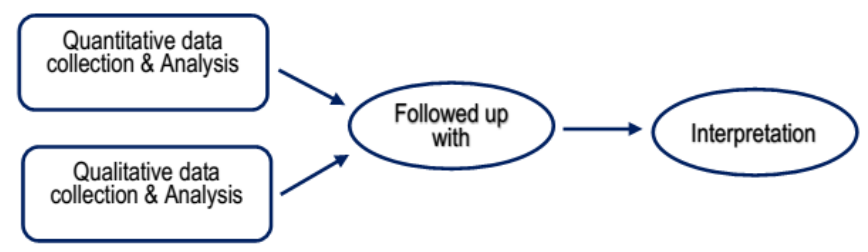


Here the researcher gains both of quantitative and qualitative data and this data will follow up and it will interpret, and then become the result of the research.

\section{Setting and Participants}

The research subjects in this research are the English Teachers in SMPN 1 Sukasada. This subject is chosen because these subjects fulfill the criteria and this school is following the rules to give online learning to the students during this pandemic. There are 11 students who give us some information about their perspective of online assessment for their speaking skill/

\section{Data Collection Method(s), Instruments, and Analysis}

As the writer stated before, the method which is used in this research is mixed method. Here the researcher uses both of quantitative and qualitative method in order to make the data of this result become trusted. The researcher will use the instruments above to get the information from the English teacher in SMPN 1 Sukasada. The data will be counted by using quantitative method and after that the data will interpreted qualitatively.

In order to gain the information, the researcher here use several instruments that given to the subjects. The first instrument is WhatsApp. The researcher used this instrument because of the limitation of activities during this pandemic. Here the researcher uses to get the general information first. Then the researcher continues by using another platform. The second instrument is Google Form, in order to get more data from the informant, the researcher uses Google Form to get the data. It is also used to avoid the outside activity during this pandemic. In this form, the researcher will give some questions that will answered by the informant.

\section{FINDINGS \& DISCUSSIONS}

\section{Findings}

The results from this research are collected by using the method above. The findings of the implementation of formative assessment by the teacher are collected by asking the teacher by using WhatsApp chat and Google Form. In order to show the respect to the informant, here the researcher uses $T$ for teacher. The researcher here used open ended interview in order to make the teacher free to say her opinion. Because of the limitation of people activity, firstly the researcher interviewed the teacher through online platform which result can be seen as follows:

\section{The perception of the teacher about assessment}

The informant here stated that the assessment is very important. By using assessment, the teacher might be able to know the students' progress during teaching. In this case the informant also said that during this pandemic, assessing the students' performance is very challenging for her. It was happened because of the lack of tools and internet connection of the students which make the teacher mostly feels difficult to teach and to assess their students.

The importance of assessment by the teacher

Based on the data from Google Form the informant stated that assessment is very important. It shown by the form which result is $100 \%$. Besides that, the researcher also asked about the time that the teacher mostly 
do assessment in the classroom. The informant stated that she had done the assessment from the beginning of the class until the end of the class. She did that in order to see the progress of the students after studied the material. Here the teacher is not only assessing the understanding of the students, but also their attitude in the class.

\section{The implementation of formative assessments in online learning.}

The informant stated that giving assessment is quite difficult during this pandemic. The students are not ready yet to do this way for learning, because of they are not having enough internet data to join the class and some of them stated that they do not have any gadgets to join the online class. Therefore, the teacher here just gave the students some assignment, in order to know their progress and to train the students' skill. Here the informant chooses Speaking Skill as the most challenging skill to assess during this pandemic. Because, speaking skill cannot be assessed by using paper assignment. The informant stated that she cannot assess the speaking skill and unfortunately, she only can assess the reading and writing skill because of the previous problem. The informant stated that she did the assessment by using rubric that she got from school that already matched with the online learning.

The researcher also uses questionnaires to the students in order to know their perception about the use of formative assessment about their speaking skill during this online learning. The researcher shared the link of Google Form to the students and told them to give their opinion about some statements. Most of them are agree about the statement that provided by the researcher. The result of the questionnaire can be shown as follows:

Table 1: students' perception of formative assessment through online learning

\begin{tabular}{|c|c|c|c|c|c|c|}
\hline \multirow{2}{*}{$\begin{array}{l}\text { Aspect } \\
\text { Percentage } \\
\text { Response }\end{array}$} & \multicolumn{5}{|c|}{ Interpersonal Relations (\%) } & \multirow[b]{2}{*}{$\begin{array}{l}\text { Average } \\
(\%)\end{array}$} \\
\hline & Q1 & Q2 & Q3 & Q4 & Q5 & \\
\hline Agree & 45,5 & 63,6 & 100 & 54,5 & 63,6 & 65,44 \\
\hline Neutral & 18,2 & 9,1 & 0 & 45,5 & 36,4 & 21,84 \\
\hline Disagree & 36,4 & 0 & 0 & 0 & 0 & 7,28 \\
\hline
\end{tabular}

The table 1 shows that the students mostly have same perception about assessment through online learning. The students answer from question number 1(Q1) shows score $45,5 \%$. It means, most of the students agree that speaking skill is the hardest skill for the students. $18,2 \%$ students choose neutral which means they sometimes feel difficult or sometimes they feel easy in speaking. Last but not least 36, 4\% students choose disagree because they thought that speaking is not difficult for them. For question number 2 (Q2) shows that the students agree with the statement because it shows $63,6 \%$ agree result. The rest of them show $9,1 \%$ chooses neutral for the question number 2 . The highest score of agree shows from the question number 3 (Q3) it shows that $100 \%$ students agree with the statement. For the question number 4 most of the students choose agree, we can see that the result of the option agree shows 54 , $5 \%$ which is higher than the neutral option which shows $45,5 \%$ and the disagree option which shows $0 \%$ for this question. The last question is Q5. The students also mostly choose agree option of this question which shows $63,6 \%$ students 
agree and $36.4 \%$ students choose neutral for this question. The higher average score from this data is the agree option which shows 65,44 students agree with those 5 questions.

As shown on the result above which stated about the teacher implementation of assessment, she stated that she always does the assessment and she always pays attention to the students from the beginning until the end of the learning process. However, after this pandemic she cannot assess the student properly, as she stated in the Whatsapp chat, she only can assess the writing and reading skill. Most of the students do not have any gadgets and they live in the village which do not have proper internet connection. Therefore, it is a big deal for the teacher because she should be able to re-design the learning process especially in assessing their students. This is her answer through chat according to the 1 question:

\begin{abstract}
"We provide the learning process through WhatsApp due to the Covid-19 pandemic considering that not all of students are able to use another application, such as; Google Classroom. It also causes by the geographical aspect in which the located of students' house where they cannot access the internet connection well. Therefore, I send the exercise and learning material through WhatsApp only."
\end{abstract}

"So, I only teach them how to write and read but there are still many students who don't submit their works on time as what happens today in which I come to their homes in order to ask them to submit their works"

The researcher also asked about the instrument that she mostly uses to assess the students in this online learning. She stated that she only gives them some tasks and then the students should submit it through WhatsApp. As the explanation before, the skill that she can only assess during this online learning are only reading and writing. The rest skills like speaking cannot be assess, because she does not want the students feel difficult in doing their task like taking video or other. Here is her answer about this part:

"The teachers use the journal list which is sent to the school"

"On another side, the students are only given some questions or worksheets"

"As what I teach them about comparison degree and I send them the learning material and some questions in School's journal"

"However, it is not difficult to assess the students by using Google Classroom but the real condition is students send their answers and works through WhatsApp, so I need others' help to check it"

From those results, it shows that the implementation of speaking skill cannot be assessed during this online learning. Even though the speaking skill is very important, the researcher also gives some questions which are given to the students about their perception of speaking skill and assessment for the speaking skill. Here the students mostly said that the speaking skill is very important. The students also stated that the speaking skill is very useful for them, therefore it is the challenging for them, because, they cannot train themselves to use their speaking skill through online learning. The students also agree with the statement that stated "assessing speaking skill can be assessed by giving task" 
they agreed if they got task in order to train their speaking skill. But, after the researcher compare with the teacher's perception, it is not match. Therefore, both of them should be able to coordinate, in order to get the decision for their future.

According to Salam and Khalek (2009) as their result in their research, the use of traditional assessment cannot be held properly for the students' skill. Because by using traditional assessment, the students cannot see their development in learning the language skill. Therefore, the use of formative assessment is the most apropiate way in assessing the students' language skill. It will affect the students' ability in using those four skills, because in the formative assessments the teacher will give feedback to the students which can be the motivation for them to develop their skill.

\section{CONCLUSIONS}

In this study, the use of the formative assessment cannot be used because of the lack of the tools. Formative assessment will be easier if the teacher and the students have face-to face meeting, in order to know the development of the skills of the students. This study conducts the data from the teacher and the students from SMPN 1 Sukasada who follow the rules from the government to do online learning. The result of this study the researcher got one of the skills which hard to assess during this pandemic is speaking skill.

\section{REFERENCES}

Arhin, A. K. (2015). The Effect of Performance Assessment-Driven Instruction on the Attitude and Achievement of Senior High School Students in Mathematics in Cape Coast Metropolis, Ghana. Journal of Education and Practice, 6(2), 109-117.

Bland, L. M., \& Gareis, C. R. (2018). Performance Assessments: A Review of Defintions, Quality Characteristics, and Outcomes Associated with Their Use in K-12 Schools. Teacher Educator's Journal, 11, 52-69.

Bozkuş, K., \& Bayrak, C. (2019). The Application of the Dynamic Teacher Professional Development Through Experimental Action Research *. 11(4), 335-352. https://doi.org/10.26822/iejee.2019450792

Clark, I. (2011). Formative Assessment: Policy, Perspectives and Practice. $158-180$.

Creswell, J. W. (2012). Educational research: planning, Conducting Evaluating, quantitative and qualitative research (Fourth Edition) (Fourth Edi). United Inc. State of America: Pearson Education.

Doyle, L., \& Brady, A. (2009). Research in Nursing An overview of mixed methods research. October 2014. https://doi.org/10.1177/1744987108093962

Franzén, M. (2020). BLUE PAPER: Covid-19 quick-test. March, 2-6. https://doi.org/10.31219/osf.io/jpukc

Heritage, M. (2010). Formative assessment and next-generation assessment systems: Are we losing the opportunity? Council of Chief State School Officers (CCSSO) http://www.edweek.org/media/formative_assessment_next_generation_heri tage.pdf

Hosni, S. Al. (2015). Speaking Difficulties Encountered by Young EFL Learners Speaking Difficulties Encountered by Young EFL Learners. January. 
Irfan Tosuncuoglu. (2018). Assessment for Learning.

Jimaa, S. (2011). The impact of assessment on students learning. Procedia Social and Behavioral Sciences, 28(January), 718-721. https://doi.org/10.1016/j.sbspro.2011.11.133

Lestiyanawati, R., \& Widyantoro, A. (2020). Strategies and Problems Faced by Indonesian Teachers in Conducting E- Learning System During COVID-19 Outbreak. Journal of Culture, Literature, Linguistic and English Teaching, 2(1), 71-82.

Lorenzo, F., Casal, S., \& Moore, P. (2020). he Effects of Content and Language Integrated Sections, Learning in European Education: Key Findings from the Andalusian Bilingual Evaluation Project. Applied Linguistics, 31(3), 418442.

Qureshi, I. A. (2017). The Importance of Speaking Skills (Issue 5655). Alama Iqbal Open University, Pakistan.

Rust, C., O'Donovan, B., \& Price, M. (2005). A social constructivist assessment process model: How the research literature shows us this could be best practice. Assessment and Evaluation in Higher Education, 30(3), 231-240. https://doi.org/10.1080/02602930500063819

Salam, A., \& Khalek, A. (2009). The Effect of Classroom Performance Assessment on EFL Students' Basic and Inferential Reading Skills. November.

Sewagegn, A. A. (2019). A Study on the Assessment Methods and Experiences of Teachers at an. 12(2), 605-622. 